\title{
The Mbira Metaphor: Inspiring Creative Thinking through Folktale
}

\author{
Constantine Ngara \\ The University of British Columbia
}

\begin{abstract}
The paper presents the author's views on inspiring creative thinking among students through a folktale. The mbira metaphor is this author's interpretation of a unique African (Shona) folktale that has the potential to enrich the pedagogy of giftedness. The mbira metaphor is an informative and thought-provoking folktale originating from previous studies on Shona culture's views of giftedness. The recognition of the mbira folktale as a metaphor that has the potential to enrich gifted programming follows new thinking in research that values the contribution of sociocultural perspectives to our understanding of giftedness and creativity. The author recommends that the mbira metaphor be used in gifted programming to inspire creative thinking among students.
\end{abstract}

While acknowledging lack of agreement in how different countries define creativity, Sternberg (1999) noted that what is generally agreed upon is that creativity describes thinking that produces original ideas and products. Corroborating this general understanding of creativity, Misra, Srivasta, and Misra (2006) understand creativity as "contributing something original or novel and useful to the domains of objects and ideas" (p. 421). However, Vygotsky (2004) argued that creativity is not just about selected works of a few historical geniuses or talented scientific discoverers, but is present in actuality. It involves imagining and combining ideas, altering something and producing something new. While Vygotsky asserted that all humans have the capacity to create, Runco (2004) believed that "not everyone is fulfilling his or her creative potential" (p. 24). Also corroborating the view that humans have vast potential for creativity which is not realised, Dalal (2001) asserted, "We are not only what we know of ourselves but immensely more which we do not know; our momentary personality is only a bubble on the ocean of our existence" (p. 337). Much more needs to be done to unleash students' creativity. However, much as educators desire to foster students' creativity in education, this goal remains elusive. Hence, the purpose of this paper is to share the author's vision for inspiring students' creative thought through folktale (the mbira metaphor) in the quest to inform the pedagogy of giftedness from a sociocultural perspective. As informed by previous studies on Shona culture's 
views of giftedness (Ngara \& Porath, 2004), cultural notions of intelligence and talent are inferred in orature. Orature refers to orally composed and functionally transmitted literature (waThiong'o, 1986).

\section{Cultural Context of the Mbira Metaphor}

Mbira is a Shona (Zimbabwean) musical instrument descriptively known in the West as thumb-piano. The mbira metaphor is the author's interpretation of an age-old African (Shona) folktale whose storyline is centered on the ownership of the mbira musical instrument. According to a Shona proverb, possessing a mbira musical instrument does not turn one into a musician. In other words, while individuals may possess potential for talent development, not many of them turn their talent potential into eminent achievements. This piece of wisdom seeks to challenge individuals to strive to develop their inborn potential into talent. In this paper the mbira metaphor is dramatized by wild animals; it satirizes the Shona cultural notion that gifts are given to all, but lost to some through human vices (Mpofu, Ngara, \& Gudyanga, 2007). In Shona culture, every child is believed to be born gifted (Ngara, 2007). In this folktale, the mbira musical instrument symbolizes chipo (giftedness); chipo is believed to be given to individuals by the greatest Spirit [Mu-ari -One Who is-God through the mediation of their ancestors (Mpofu et al., 2007)]. In Shona cultural thinking, chipo can be given and lost through human vices such as laziness, selfishness, wickedness, and disrespect of elders (Ngara, 2006). The folktale satirizes laziness, lack of imagination, and stagnation as personified in the character 'Baboon' (see the story below).

The setting of the mbira metaphor is Shona (Zimbabwean) traditional culture. In Shona folktales, giftedness and/or creativity are epitomized in the little animal 'Hare' (rabbit) while Baboon personifies the opposite-foolishness, dullness, and conceit (Fortune, 1980). To understand the metaphor in the story, one may have to shelve one's knowledge of scientific assumptions about which animal is actually more intelligent, the hare or the baboon. Typically, in Shona cultural values, folktales are attributed to sarungano (the unknown story teller) and they are neither owned nor identified with any particular individuals (Mpofu et al., 2007). As such, anyone can use them for common good.

\section{The Mbira Metaphor}

Once, in a distant land, Baboon was employed by forest animals to entertain them when they came home every day after a hunt. The animals liked to be treated to some music as they arrived home after a hunt and Baboon played them mbira music. Although Baboon's music was always flat, dull, and uninspiring, the animals were content with his mbira sounds for, in their world, they knew no better music with which to compare. Who could blame them? Baboon played them the only sounds they knew and he was serving them faithfully day-by-day.

One day, Hare passed by while the animals were out hunting and requested to learn how to play mbira music. Baboon agreed. Soon Baboon engaged Hare in learning his mbira thumbing techniques. As Baboon demonstrated his mbira thumbing techniques, repeating his usual tune, Hare keenly observed and listened, searching for rhythms, thumbing patterns, and alternations and repeats. Hare was an incredibly rapid learner for, in no time, he had mastered all the rudiments of Baboon's mbira thumbing techniques. The moment he commenced learning mbira 
music, Hare found mbira thumbing so fascinating that he did not want to stop. Baboon had to send him away as the animals were returning home from their hunt. Hare went home, promising to come back the following day to continue his mbira music lessons. As he went home, Hare could not stop thinking about mbira music. Even when he slept, he had a wonderful dream about making mbira music.

The following day Hare returned to Baboon for further mbira music practice. In no time he had mastered all of Baboon's mbira thumbing techniques to the extent that he was already playing as if he were experienced. Again Baboon had to push him away and take back his mbira set before the animals returned home. When Hare went home, he was still rehearsing mbira thumbing techniques in his head. He even hummed an imaginary tune that he wanted to try the following day. At daybreak the following day, Hare came back to Baboon to play mbira music. With his good ear for music, Hare soon realized that Baboon's music was monotonous. While practicing mbira music, it occurred to Hare that Baboon's techniques left out some of the high keys of the mbira musical instrument and that if these were included in the rhythms this could produce music with a difference. Convinced that the mbira set could be played in another way with different results, Hare kept trying to play mbira music by varying different sets of key combinations and alternations different from what he had learned from Baboon. Hare was obviously looking for something although he was not sure what it was. Owing to his immense interest in mbira music, Hare wanted to play mbira music forever.

While on his way home, Hare could see all the mbira keys in his mind. As he slept, he dreamt about playing the most wonderful music that echoed in the forest. In his dream, he saw animals of different kinds dancing around him to his new tune like they were mad. When next he visited Baboon to play mbira music, Hare simply wanted to play mbira music in a unique way. He tried thumbing a variety of different combinations of top, middle, lower, and side keys, alternating them with repeats and listening to the results. In the process, he hit certain key combinations, alternations, and repeats that produced unbelievably sweet musical rhythms never before heard anywhere in the land. When Hare accompanied his mbira thumbing with soft vocals of his own lyrics, Baboon was taken aback. When he heard Hare's rhythms, Baboon thought Hare's music skill was totally out of this world. Suddenly Baboon was up and dancing as if he were possessed of a spirit. With only a few days of mbira thumbing practice, Hare's music made Baboon dance like mad. Meanwhile, the animals were returning home from their hunt at the end of the day. As they drew nearer home, the animals caught the magical rhythms for the first time. Something was different! There was no mistake about it! They were neither dreaming nor imagining. The most wonderful music of all time was echoing from their forest home like a milliard of buzzing bees.

"Listen to that! Just listen again! Did I not hear well!" cried Kimba (Lion cub) excitedly. "This is the music we've been waiting for all these years! I bet our Baboon must have had a magic dream to produce such wonderful sounds!" granted Simba (Lion King). "I like it. Let's go home dancing in style!" shouted Kimba as Duiker leapt above trees while Hyena tried a belly dance. Not to be outdone, elephants uprooted a few trees, echoed their trumpets, and saluted. Thanks to the elephants' trumpets, Baboon came back to his true senses. Goodness knows the animals were approaching! Frightened and panicking, Baboon suddenly grabbed back his mbira set and pushed Hare away roughly, sending him away immediately. Hare quickly vanished into the woods.

Suddenly, the tempo of music changed! The animals stopped dancing as the tempo switched back to the usual dull and flat tune. What a stupid trick Baboon must be playing! What 
does this mean? The animals could not stand it. Puzzled, disappointed, upset, and furious, they mobbed Baboon and hurled curses of every kind at him. The animals were not amused by Baboon's excuses and apologies. They spat, rasped, and ruffled him a bit, pushing him to play the most wonderful music of all time which they had clearly heard. "Damn Baboon! You big tailed Baboon, Baboon of the forest! Bloody Baboon of the mountains!" All the animals vented their anger on Baboon. "Don't do this to us! Play your new tune before your bones start snapping in my mouth!" rumbled Simba the Lion King. But Baboon continued to play mbira the only way he knew, pleading for mercy and muttering more apologies between his teeth, "Tha-That-That is ho-how- I-I always pla-play. What you he-heard was my accidental tune."

"Shut up! Play your accidental tune now!" rasped Hyena, craving the honour of crushing Baboon's bones. "Don't play us this dirty trick again tomorrow! If you don't remember your accidental tune by tomorrow, I swear that you might not see sunlight again!" roared Simba. The following day the animals went hunting as usual. When Hare came back very eager to practice mbira music further, Baboon was unwelcoming. His face downcast, he barked, "Go away Hare, just go away! I don't want to see you anymore. Do you know what they did to me because of you? You nearly got me killed. It's you who brought me this trouble here, just go away now with your skills! See now! You have upset the forest harmony!" Hare mumbled his apologies to Baboon, pleading with him to be allowed to play for just a short time. He used his sweet tongue to persuade Baboon. "Baboon Sir, Great Baboon of the Mountains! Just let me play only once for the last time. I just want you to hear my dream song for a few minutes. How I love to see your great dancing antics! Please Great Baboon of the Mountains, just allow me to play for the last time. I'll make it short and memorable for us," Hare begged, already reaching for Baboon's mbira set. Flattered, Baboon gave in and allowed Hare to play the mbira but warned, "Only for a short time. I mean it!" he barked.

Once Hare got the mbira set, he meant serious business. As he played mbira sounds, Baboon heard again the sweetest music of all time and lost his wits. Forgetting everything else in the world, Baboon was once more up and dancing like he had never done before. Unbeknown to them both, they were being watched from a tree branch by a pair of large eyes. Someone patient was lying lazily and quietly spying on them. Having seen what he wanted to see, he climbed down in his cat style without even breaking a twig. Soon Simba the Lion King would know everything. As the animals were returning home after their hunt, once again they heard the sweetest music of all time echoing in the woods, like in a dream. The animals became excited once more. As they approached, the wonderful rhythms echoed louder and louder from their forest home.

The animals approached their forest home, dancing excitedly all the way. Baboon heard them coming and jumped at Hare, panicky and confused as if he were waking up from a dream. It was too late! Just as he grabbed the mbira set and tried to push Hare away, Simba the Lion King was on the scene! Hare could not sneak away, for Simba held him back and blocked his hasty departure. Grabbing the mbira set from Baboon and roughly pushing him away, Simba gave back the mbira musical instrument to Hare and ordered him to continue playing his wonderful music. Hare played yet another tune whose rhythms excited the animals as they approached. The animals arrived home in style, dancing with excitement. They jived and danced until a few of them collapsed and fainted. After the animals were tired of dancing, they unanimously declared a vote of no confidence in Baboon's music and declared Hare their official forest entertainer. The mbira set was given to Hare and Baboon was immediately dismissed without honour. Dissatisfied with the animals' judgment, which he called 'rule of the jungle,' Baboon went to appeal for justice to the wise elders of the village court. He wanted to recover his mbira 
set from Hare. The wise elders of the village listened carefully to his story and asked him few questions.

"As we were not there, how can we know for certain that the mbira set you're claiming was ever yours?" "It's my mbira set because it was mine before it was taken away from me," Baboon explained. "Is your mbira set marked with your totem symbol or sign that we can see?" "No, my elders, but I know you are wise judges, wiser than animals. I know that you have finer laws and you don't follow jungle rules like animals. I know you'll rule in my favour because the mbira set in question is mine. It was mine before it was taken away from me." "But, how can we tell for certain that you once owned this mbira thing that you talk so much about?" "I play mbira music the way it has always been played by all mbira players who came before us. Now Hare comes along and plays me his silly tricks of changing - changing things just like that. Then, I get kicked out from my job of entertainer of the forest because Hare is jealous of me. Nobody can even tell what songs he plays. He also shows no respect for our tradition as you too will witness," Baboon told the elders with a nod, stressing his point. The wise elders summoned both Hare and Baboon to the village court. They asked Hare to hand forth the mbira set and Baboon was requested to present his case against Hare. Then, Hare was asked to give his side of the mbira ownership story. "As we were not there when this mbira set changed hands, each of you will be required by our court to convince us that you own the mbira set by demonstrating how much you know this musical instrument." Both Hare and Baboon agreed to prove their ownership of the mbira set through a thumbing contest. Baboon was honoured with the first chance to play his music. While he played his sounds, he sang these lyrics, claiming ownership: "This mbira is my mbira. My mbira is my mbira. It was my mbira before it was stolen from me. I always played my mbira our traditional way...My mbira is my mbira." As Baboon played his music, he shook his head like a champion. The wise elders nodded in approval. After Baboon finished his show, the elders clapped hands for him and thanked him while he nodded and laughed mockingly at Hare. Then, it was Hare's turn to present his music show. Before playing, Hare requested to briefly check the instrument to be sure if it was in tune. He corrected a few keys that were apparently out of tune.

As Hare began thumbing his mbira music, they all heard wit-shattering music never heard before anywhere in the land. For the first time in their lives, the elders and the villagers enjoyed the most wonderful music of all time with rhythms and repeat patterns of falling rain punctuated with a cadence of a milliard of buzzing bees. Hare accompanied his mbira sounds with sweet lyrics sung in a soft voice modulated right in his throat. In his lyrics, he claimed ownership of the mbira set. "This mbira is my mbira; just listen when I play it. My mbira is your mbira; see how you dance to it when I play. If you can't play like me, you can dance like yourself, for when I play, we all play, my mbira is our mbira, let me play our mbira." Hare's mbira sounds blended sweetly with his lyrics, producing incredibly wonderful and tantalizing rhythmic melodies that mesmerized villagers and left their mouths agape. Who would not dance to such wonderful music? But who really was the first to dance if it was not Baboon himself? True to his nature, unable to resist the urge to dance, he was suddenly up and dancing a wild and vigorous breakdance much to the amusement of the adjudicating elders and the village audience who had gathered to enjoy the show. Women of the village ululated and also started dancing. Not to be outdone, the elders also joined in the dance. When they were all tired of dancing, the wise elders took the mbira set from Hare while the village audience was shouting for more of Hare's music, "Encore! Encore! Another piece!" 
In the end, the wise elders of the village announced their judgment. Their decision was unanimous in favour of Hare. Baboon lost the mbira set again. Once more Baboon left the village unceremoniously. The elders congratulated Hare for treating them to wonderful music that was beyond their imagination. They encouraged him to keep on perfecting his music, suggesting that it would one day awaken even the dead to join in the dance. Since then, mbira music has continued to become more creative and hence more interesting.

\section{Telling the Story}

There is useful anecdotal evidence from responses of both children and adults who listened to the mbira metaphor during the writer's voluntary storytelling work in Canada. Among the adults, the mbira metaphor was told at The University of British Columbia, Canada, during an Africa Awareness function jointly hosted with the Global Student Speakers Bureau. The folktale also was told at three primary schools in Vancouver to students from grades 3 to 7 . Students from two of the schools were in gifted programs. During his storytelling, the author livened the folktale by playing live mbira music, capturing interest and provoking discussion.

In their response to the mbira metaphor, children in one Grade 3 class were concerned about moral issues of fair play, provoking an interesting debate between Baboon sympathizers and Hare supporters (who preferred the animals' and village court-elders' decisions). In this context, all of the children's opinions were welcome. Perhaps showing lack of understanding of the deeper meaning of the folktale, one little girl suggested that Hare should have looked elsewhere for his own mbira set so as not to dispossess Baboon. However, after noticing that all the children had earlier unanimously suggested giving Hare the mbira musical instrument, to resolve the argument the storyteller asked them to vote again if they wanted to change their decision. No one suggested giving Baboon the mbira set. Another girl in the same class stunned the storyteller by relating the mbira metaphor to the parable of the talents (Matthew 25 v.14-30) ${ }^{1}$. In grades 6 and 7 classes, students were not much concerned about moral issues of fair play. These students came up with applications of the metaphor to their own lives, such as striving to be more imaginative and creative in their lives, being conscious of the possible existence of their talent potential which they need to develop and learning from others (as epitomized by Hare). Although younger children no doubt enjoyed the mbira metaphor as a story and engaged in exciting debates, this metaphor may be more appropriate to late elementary to secondary school students. ${ }^{2}$

\section{Conclusion}

This paper shared the author's vision for inspiring creative thinking among students through folktale. Mythological literature contains archetypes linked to creativity in real life (Rao, 2005). The mbira metaphor contributes to current debates on understanding how individuals de-

\footnotetext{
${ }^{1}$ In the Christian New Testament, Jesus told his disciples the Parable of the Talents (a talent is an ancient coin). In the parable the master who was going away divided his money between his three servants. To the first servant he gave five talents; to the second servant he gave three; and to the third servant he gave one talent. The first two servants invested their talents and doubled them. When the master returned he was very pleased with them. The third servant buried his talent. When the master returned, he was displeased with him and took away his talent and gave it to those who had made more talents.

${ }^{2}$ In the absence of Mbira music CDs, mbira music videos can be downloaded from youtube.com.
} 
velop talent. As illustrated by Mpofu et al. (2007), "Hare wins ownership of the mbira set from a combination of dispositional qualities, including rapid learning, high task motivation, social intelligence, and supportive environment (availability of mbira stimulus, a challenge paused by the contest, and judges)" (p. 224). As confirmed by Phillipson (2007), sociocultural conceptions of giftedness can inform gifted education. In particular, the mbira metaphor engages students in provocative discourse about understanding and developing their own talent potential. The mbira metaphor satirizes talent loss and talent development from Shona culture's perspective. In Shona culture's view, possession of a mbira set does not turn one into a musician. This means that possessing inherent talent is not a sufficient condition for eminent achievement. One has to consciously seek to develop his or her inherent gifts into talent. The storyteller therefore challenges individuals to critically examine how they might be forfeiting their own chances for talent development. Hence, the need to expose students to opportunities for reflecting on and debating issues of talent development (as offered by the mbira metaphor) is emphasized in this paper. The more students are exposed to such opportunities, the more they are likely to consciously seek to develop their own talents. As informed by a renowned Zimbabwean artist (as cited in Ngara, 2008), Creativity is like music, when you hear it that is when you know you have your own way of playing it.

As stories have a powerful effect on children, it is hoped that the mbira metaphor will stimulate students' creative thought through modelling creative behaviour (as epitomized by Hare). Folktale is a rich source for understanding Shona culture's conceptions of giftedness, as revealed in previous studies (e.g., Mpofu et al., 2007; Ngara, 2006, 2007; Ngara \& Porath, 2004). There is a need for further studies to investigate how creative practices are depicted in folktales and mythologies across cultures in order to inform culturally relevant programming in gifted education.

\section{References}

Dalal, A. S. (2001). A greater psychology: An introduction to the psychological thought of Sri Aurobindo. New York: Tarcher/Putnam.

Fortune, G. (1980). Ngano. Salisbury, Zimbabwe: Mercury Press.

Jordan, A. J., \& Porath, M. (2006). Educational psychology: A problem-based approach. Boston: Pearson, Allyn \& Bacon.

Matthew (25 v.14-30). The Parable of talents. The Holy Bible. English standard version.

Misra, G., Srivasta, A. K., \& Misra, I. (2006). Culture and facets of creativity: The Indian experience. In J. Kaufman \& R. J. Sternberg (Eds.), International handbook of creativity (pp. 421-455). New York: Cambridge University Press.

Mpofu, E., Ngara, C., \& Gudyanga, E. (2007). Giftedness among the Shona of Central and Southern Africa. In N. S. Phillipson \& M. McCann (Eds.), Conceptions of giftedness: Sociocultural perspectives (pp. 225-251). Mahwah, NJ: Lawrence Erlbaum.

Ngara, C. (2006). Indigenous conceptions of giftedness in Zimbabwe: A comparison of Shona and Ndebele cultures of Zimbabwe's conceptions of giftedness. International Journal of Education, 36(1), 46-62.

Ngara, C. (2007). African ways of knowing and pedagogy revisited. Journal of International Education. Special Issue on Indigenous Ways of Knowing, 2(2), pp. 7-20.

Ngara, C. (2008, June). Tall-tales of giftedness and creativity: An African perspective. Paper presented at the Annual Congress of Humanities and Social Sciences, CSSE, University of British Columbia, Vancouver.

Ngara, C., \& Porath, M. (2004). Shona culture of Zimbabwe's views of giftedness. High Ability Studies, 15, 189209.

Phillipson, S. (2007). A framework for the study of sociocultural perspectives of giftedness. In N. S. Phillipson \& M. McCann (Eds.), Conceptions of giftedness: Sociocultural perspectives (pp. 1-33). Mahwah, NJ: Lawrence Erlbaum. 
Rao, C. R. A. (2005). Myth and the creative process: A view of creativity in the light of three Indian myths. Creativity Research Journal, 17(2-3), 221-240.

Runco, M. (2004). Creativity as an extracognitive phenomenon. In L. V. Shavinina \& M. Ferrari (Eds.), Beyond knowledge: Extracognitive aspects of developing high ability (pp.17-25). Mahwah, NJ: Lawrence Erlbaum.

Shavinina, L.V., \& Ferrari, M. (2004). Beyond knowledge: Extracognitive aspects of developing high ability. Mahwah, NJ: Lawrence Erlbaum.

Simonton, D. K. (1984). Genius, creativity and leadership: Historiometric inquiries. Cambridge, MA: Harvard University Press.

Sternberg, R. J. (Ed.). (1999). Introduction. In J. C. Kaufman \& R. J. Sternberg (Eds.), International handbook of creativity (pp. 1-9). New York: Cambridge University Press.

Vygotsky, L. S. (2004). Imagination and creativity in childhood. Journal of Russian and Eastern European Psychology, 42(1), 7-97.

waThiong'o, N. (1986). Decolonizing the mind: The politics of language in African literature. London: Heinemann.

\section{Author's Note}

Correspondence concerning this article should be addressed to Constantine Ngara, Bahrain Teachers College (BTC) S-22, University of Bahrain, P.O. Box 32038, Sakhir Campus, Manama, Kingdom of Bahrain. Email: cnstnga@yahoo.com 